08-083

\title{
Where Does it Go? \\ Spending by the \\ Financially Constrained
}

\author{
Shawn A. Cole \\ John Thompson \\ Peter Tufano
}




\title{
Where Does it Go? Spending by the Financially Constrained
}

\author{
Shawn Cole, John Thompson and Peter Tufano*
}

In this paper, we analyze the spending decisions of over 1.5 million Americans who vary in their degree of revealed credit constraints. Specifically, we analyze how these Americans spend their income tax refunds, using transaction-level data from a stored-value card product. Card-holders may choose among several tax settlement and loan options, effectively receiving cash as much as 90 days earlier than would have been possible without a settlement product. Those selecting earlier settlement options pay higher fees and interest, therefore revealing the level of credit constraints or impatience. We find that more credit constrained or impatient individuals spend their monies more quickly. The mix of cash and merchant transactions is similar between more and less constrained groups. Finally, the primary merchant uses of refunds are to pay for necessities (grocery stores, gas stations, etc.), and the fraction of the refund spending devoted to these necessities is higher for those with greater revealed credit constraints.

Rev: April 11, 2008

*Contact Information: Shawn Cole, Harvard Business School, Boston, MA 02163 (scole@hbs.edu); John Thompson, H\&R Block One H\&R Block Way, Kansas City, MO 64105 (jthompson@hrblock.com); and Peter Tufano, Harvard Business School, Boston, MA 02163 (ptufano@hbs.edu) and NBER and D2D Fund, Inc. Prepared for the Harvard Joint Center on Housing Studies Symposium on "Understanding Consumer Credit." We would like to thank David Hussong at H\&R Block for excellent research support, and Eric Belskey, Ren Essene, Annamaria Lusardi, Chuck Muckenfuss, John Campbell, Daniel Schneider, Robert Weinberger, and participants at the JCHS Symposium for helpful comments. Cole and Tufano thank the Division of Research of the Harvard Business School for financial support. The views in this paper do not represent those of the H\&R Block Corporation. No personally identifiable information of Emerald Card holders was shared with the authors of this study. 
Despite widespread interest by academics, business people, and policy-makers, much is unknown about the financial behavior of low-income individuals, particularly the unbanked and underbanked. We examine the spending patterns of low and moderate income households, using a new database, and focus on differences in spending as a function of consumers' credit constraints. Our work leverages a unique and proprietary dataset of spending information on over 1.5 million individuals to shed light on important questions at the intersection of consumer credit and consumer spending: Do credit constrained consumers spend money more quickly than less constrained consumers? Do they spend the money in different manners (card-based merchant transactions versus cash ATM withdrawals)? Finally, do credit constrained consumers have different spending patterns than the less constrained—do they buy different goods and services?

We answer these questions by analyzing data from H\&R Block Bank, a subsidiary of the nation's largest commercial tax preparer, ${ }^{1}$ on how $1,543,553$ individuals spent their tax refunds in 2007. Tax refunds represent a substantial source of liquidity for the American population: in aggregate, in the 2007 tax season, the IRS paid out \$233.7 billion in refunds to 103.5 million taxpayers for an average refund of $\$ 2,259 .{ }^{2}$ Many of Block’s clients are low to moderate income (LMI) individuals, who are eligible for, and claim the federal Earned Income Tax Credit (EITC), among other refunds and credits. These tax refunds represent material payments for low income filers. Nationwide, among families with adjusted gross incomes below $\$ 30,000,84 \%$ received

\footnotetext{
${ }^{1}$ See Tufano and Schneider (2004) and Rose, Schneider and Tufano (2006) for additional background on H\&R Block. Throughout this paper, we will refer to H\&R Block, rather than to the various Block divisions or subsidiaries, such as H\&R Block Bank or the firm's tax preparation division.

${ }^{2}$ Summary data for Tax Year 2006 (typically filed in winter of 2007).

http://www.irs.gov/taxstats/article/0,,id=96629,00.html (accessed January 20, 2008).
} 
refunds. ${ }^{3}$ The average refund size for this group was $\$ 1,617$. For those filers with positive adjusted gross income (AGI), the refund was worth an average of about 6.5 weeks of AGI. The numbers for Block clients are similar: about 57.4\% of Block clients have AGIs of \$30,000 or less and about $88 \%$ of them receive refunds. The average refund payment received in our sample, net of tax preparation fees and financing charges (discussed below), is approximately \$2,700.

Tax preparers like Block not only process returns, but also offer customers additional services, including savings, payment, and credit products. Some of these services reduce the time a client must wait to receive her tax refund. As a benchmark, for households without bank accounts, the standard method to receive a refund is to wait for a paper check from the IRS to arrive in the mail, and then cash the check. This process can take up to eight weeks. We study several related products made available to Block customers in 2007 that permitted them to accelerate receipt of funds: some enabled clients to receive the refund days or weeks before they might have otherwise received them, ${ }^{4}$ while one allowed clients to receive a loan as early as October $15^{\text {th }}$, three months before the earliest date taxes could have been filed. Importantly, each product was offered together with an "Emerald Card," a stored value card that can be used for PIN and signature based purchases and ATM withdrawals, and which leaves an electronic record which enables us to observe consumer transactions.

We use the variation in settlement and loan products to identify credit constraints and the Emerald Card transaction data to track spending. We find that (a) more credit constrained or impatient consumers spend their funds a bit faster than others; (b) the method of transaction (merchant vs. ATM) does not vary between the more and less credit constrained; and (c) more

\footnotetext{
${ }^{3}$ Detailed data for Tax Year 2005 is the most recent year available; http://www.irs.gov/taxstats/indtaxstats/article/0,id=96981,00.html (visited January 20, 2008), Table 3.3. In Tax Year 2005, approximately $50 \%$ of filers had AGIs of $\$ 30,000$ or below.

${ }^{4}$ Technically, none of the products speed up the payment of the refund by the IRS or state taxing authorities.

Rather, these products either support the payment of speedier electronic refunds or involve a loan to the taxpayer.
} 
credit constrained people spend a greater fraction of their merchant purchases on apparent dayto-day necessities, such as grocery store and gasoline purchases.

We believe our findings are important for three reasons. First, unlike most earlier studies on spending of tax refunds or rebates, our transaction-level data can precisely indicate how fast and where funds are spent. In the context of current discussions about using tax rebates as economic stimulus, our findings and methods should be of interest to policy makers who seek to understand how the monies will pulse through the economy. Second, there are heated discussions about the costs and benefits of short-term lending to LMI. Recent research focuses on one type of this lending (payday lending) to study the ultimate, but necessarily indirect, impact of this lending. ${ }^{5}$ We can examine the direct use of the borrowed funds to understand more about credit constraints. Finally, unlike most earlier studies of either tax refunds or credit, we do not study a small number of people or a small representative sample. Rather, our large database allows us to study how over $\$ 3.6$ billion was spent in a relatively short time by 1.5 million low to moderate income families, nearly $1.5 \%$ of all refund recipients nationally.

In the remainder of this chapter, we first review the existing literature on spending and credit constraints. Next, we provide detail on the various loans and settlement products offered by Block that reveal credit constraints or impatience. Next, we describe the database of transaction records and provide baseline data on the various spending metrics, which are speed of spending, mode of spending (cash vs. merchant) and merchant category. Turning to how spending patterns vary with the level of impatience or credit constraint, we analyze spending patterns for the most “impatient” spending, which occurs before the client could have received money had the loan or settlement product not been used. We then study how behavior varies by

\footnotetext{
${ }^{5}$ See Morse (2006), Skiba and Tobacman (2007) and Melzer (2007).
} 
degree of credit constraint. Finally, we conclude, and discuss implications of our findings and future extensions of this work.

\section{$\underline{\text { Related Work }}$}

As a study of spending patterns related to tax refunds, our work relates to the extant research on the planned and actual use of tax refunds. Tax refunds, in particular the Earned Income Tax Credit (EITC), are an important public policy tool, redistributing income to support low income families. The EITC is a refundable tax credit, supplementing the income of lowincome families with children. ${ }^{6}$ A relatively large literature has developed around the EITC. While much attention has focused on the effects of EITC on labor supply ${ }^{7}$, a parallel literature examines the impact of refunds (or tax rebates) on the marginal propensity to consume and save, as well as the type of consumption supported by tax refunds. Scholars have taken two main approaches to this question.

First, a number of studies use qualitative methods or small-sample surveys to collect data directly from tax filers on the use of refunds. Some of these studies are specifically geared towards understanding the use of refunds (Olson and Davis, 1994; Romich and Weisner, 2000; Smeeding, Ross, and O’Conner, 2000; Schneider and Tufano, 2006). Others collect this data almost incidentally in the course of assessing the effect on savings of interventions designed to offer bank accounts at tax time (Beverly, Tescher, and Marzhal, 2000; Beverly, Schneider, and Tufano, 2006; Rhine, Su, Osaki, and Lee, 2005). A recurrent finding of this literature is that

\footnotetext{
${ }^{6}$ See, for example, Hotz and Scholz, 2003.

${ }^{7}$ Most work has focused on calculating the take-up rate or the drivers of take-up for the EITC (Scholz, 1990; Scholz, 1994; Liebman, 1996; Hill, Hotz, Mullin, and Scholz, 1999; GAO, 2001; IRS, 2002; Blumenthal, Erard, and Ho, 2005; Caputo, 2006; and Kopczuk and Pop-Eleches, 2007), estimating the effect of the EITC on marriage and fertility decisions (e.g. Baughman and Dickert-Conlin, 2003; Dickert-Conlin and Houser, 2002; Ellwood, 2000), and examining how the EITC shapes labor market activity (e.g. Ellwood, 2000; Eissa and Liebman, 1996; and see Eissa and Hoynes, 2006; and Hotz and Scholz, 2003 for reviews of the literature).
} 
filers report valuing the lump sum disbursement of refunds because it functions as a forced savings mechanism (Olson and Davis, 1994; Romich and Weisner, 2000).

Despite these intentions to save, a large share of refunds appears to be used for consumption. Across studies, a majority of respondents report planning to spend their refunds or use them to pay off debt (Romich and Weisner, 2000; Schneider and Tufano, 2006; Beverly, Tescher, and Marzahl, 2000; Rhine, Su, Osaki, and Lee, 2005). Low-income tax refund recipients put particular emphasis on plans to purchase clothing or school supplies, to maintain or purchase cars, to pay for groceries, and to catch up on credit card debt and late bills (Romich and Weisner, 2000; Smeeding, Ross, and O’Conner, 2000; Beverly, Schneider, and Tufano, 2006).

While these studies have added substantially to our knowledge of how EITC funds are used, they are limited in important ways. First, each of these studies (excepting Schneider and Tufano (2006) who study a municipal-EITC) relies on data collected from filers at Volunteer Income Tax Assistance (VITA) sites. While VITA's free tax preparation is a useful service for many low-income filers, it reaches only a tiny share of EITC filers, about 2\% in 2004 (Kneebone, 2007). This raises serious questions about the representativeness of the data used in the literature. Second, these studies only examine planned refund use, not how the funds were actually employed. Social desirability response bias, intervening events between the time of interview and the time of use, and perhaps some wishful thinking on the part of respondents, may conspire to make this data less than reliable.

A second group of studies has taken a very different methodological approach to studying the use of the EITC and other tax refunds. These collect data for spending patterns after the refund is received and use broadly representative samples, remedying some of the problems with 
the studies reviewed above. One set of these studies uses custom designed surveys to assess the effect of tax refunds on consumption. Using data from the Michigan Survey of Consumers to examine the effect of the 2001 Economic Growth and Tax Relief Reconclliation Act (EGTRRA) tax rebates (Shapiro and Slemrod, 2003), and the effect of the Jobs and Growth Tax Relief Reconciliation Act (JGTRRA) (Coronado, Lupton, and Sheiner, 2005), scholars find that about 20 percent of respondents planned to spend most of their rebates, 45 percent planned to use most of the rebate to pay down debt, and between 27 percent and 37 percent planned to save most of the funds. Liquidity constraints, proxied by income levels did little to predict the use of the funds.

Taking a different tactic, Barr and Dokko (2006) survey low-income respondents in Detroit about their use of EITC funds and find that about half spent the entire refund, 10 percent saved the entire refund, and the remainder allocated some to savings and some to spending. Those spending their refund tended to pay down debt, with smaller shares buying appliances, vehicles, or paying for education. Barr and Dokko (2006) segment their respondents by selfreported RAL receipt and find that those taking RALs were more likely to spend all of their refund (54 percent) than those without RALs (46 percent) and were also more likely to purchase appliances - 27 percent versus 19 percent.

A related set of studies uses standard consumer surveys such as the Consumer Expenditure Survey to estimate how tax policy affects consumption (Souleles 1999, 2002; Johnson, Parker and Souleles 2006; Barrow and McGranahan 2000). More specifically, several of these studies attempt to assess if, contrary to the permanent income hypothesis, spending increases in response to an expected change in income (Souleles, 1999, 2002; Johnson, Parker 
and Souleles, 2006). A related study by Stephens (2003) examines changes in consumption patterns around the receipt of Social Security payments.

Based on data from the Consumer Expenditure Study it appears that tax refund and rebate recipients do increase their spending. Souleles (1999) examines CES data from 1980 to 1991 and finds that households increase their spending, particularly on durable goods around the time of refund receipt. Most of these funds (between one-third and two-thirds) are spent within the quarter and more liquidity constrained households spend more of their refunds. Investigating a similar question using data from Reagan’s 1981 tax cut, Souleles (2002) finds similar results, though uncovers less evidence for the role of liquidity constraints. Drawing on a unique supplement to the CES on the timing of refund receipt, Johnson, Parker, and Souleles (2006), estimate that recipients spent between $20 \%$ and $40 \%$ of funds within the three month survey period surrounding receipt and as much as two-thirds within a six-month period as recipients raised expenditures on clothing, health care, and food in particular. Proxying for liquidity constraints using income and assets, Johnson, Parker, and Souleles (2006) find a significant positive effect on spending. Focusing on low-income refund recipients and the disposition of EITC funds in particular, Barrow and McGranahan (2000) find that spending increased on nondurables by about 3 percent and on durables by about 9 percent during February, the modal month of EITC receipt. Further, these funds were spent fairly quickly, with about one-fifth used within the first month of receipt.

Compared to these studies, our Emerald Card data provides accurate and extensive data on spending of a large number of individuals. It circumvents the limitations of the qualitative and small-sample literature on the EITC by using data from a commercial tax preparer rather than VITA sites, and collects extremely precise retrospective data on refund disposition rather 
than planned use. Additionally, we are able to look at the specific disposition of refund dollars, rather than the total effect of refund receipt on spending. Given evidence of mental accounting among consumers, it is an advantage to see how these particular funds are used.

We exploit differences in credit constraints or liquidity to understand spending patterns, and thus, our work also relates to a large body of work on credit constraints, payment types, and household decisions. A number of papers examine whether liquidity or credit constraints affect consumption decisions. These papers have used a host of measures of credit or liquidity constraints including savings (Hayashi 1985), asset to income ratios (Zeldes 1989), homeownership (Runkle 1991), denial of access to credit (Jappelli, Pischke and Souleles 1998), timing of the receipt of paychecks (Stephens 2006), bankruptcy (Filer and Fisher 2007) and changes of credit card credit limits (Gross and Souleles 2002; Soman and Cheema 2002).

The research closest in spirit to our work is Agarwal, Lin and Souleles (forthcoming). They study the 2001 Federal tax rebate given to households by examining credit card spending in the wake of these rebates, and like us, attempt to identify consumers with different levels of credit constraints. Our paper differs from Agarwal, Lin and Souleles in at least four ways. First, they study a one-time windfall, while we study tax refunds that are an annual part of family cash flows. The average size of the refund in our sample is much larger than the rebate they study. Second, they study general spending patterns, or more precisely, credit card transactions, which are not directly linked to the tax refund. In contrast, we observe all the transactions used to spend down the refund. While money is of course fungible in practice, our approach may more accurately capture the impact on spending if consumers engage in some type of mental accounting (Thaler 1980, 1985). A disadvantage of our method is that we do not observe how 
consumers non-Emerald card spending adjusts to the refund. ${ }^{8}$ Third, Agarwal, Lin and Souleles use age and credit limits set by credit card companies as proxies for credit constraints; we use the revealed choices of loan products to identify differences in credit constraints or liquidity. Finally, their sample is restricted to individuals that possess credit cards, while our sample includes a large number of households with little or no access to financial services and who therefore opt to use the Emerald Card.

\section{The Emerald Card: A Window into Spending Behavior}

The Emerald Card serves as a debit card, allowing Block clients to withdraw money from most ATMs, or to purchase goods and services (without transaction fees) from any merchant honoring Mastercard. It is particularly valuable to unbanked or underbanked households and Block estimated that about $60 \%$ of clients opting for the Emerald Card were unbanked.

Customers could also withdraw some or all of their balance over the counter at most banks. We therefore observe precisely how and when clients spend their money.

The Emerald Card is a stored value card, meaning that it is loaded with a certain amount of cash which is withdrawn (and possibly replenished) over time. In most cases, the Emerald Card was initially "loaded” with the client’s tax refund (less processing and financing charges) or the proceeds of the tax refund loan. Customers could add additional funds or "reload" the cards through direct deposit from their employer or at various retail locations (such as Wal-Mart, Radio Shack, and others) that serve as 'reload centers.' With the ability to reload, the card could serve as a permanent payments transaction account. The card by itself provided no credit either

\footnotetext{
${ }^{8}$ A further complication is that spending may vary depending on the payment mode used (cash, check, credit card, debit card, stored value card, etc.) For example, see Hirschman 1979, Feinberg 1986 and Prelec and Simester 2001. These studies tend to find different behaviors (more spending or a willingness to pay more) when credit cards are used instead of cash. The Emerald Card is not a credit card, and may not behave the same as a credit card.
} 
explicitly or in the form of courtesy overdraft. ${ }^{9}$ The card also carried consumer protections and capabilities that made it the equivalent of a checking account, with the exception of paper checks and no ability to 'overdraw' the account. Like most checking accounts, funds on the Emerald Card did not earn interest, and like most ATM cards, there were various fees associated with its use. ${ }^{10}$ During the period in review, the average Emerald Card user paid approximately $\$ 12-\$ 14$ in card fees related to receiving and using their refund proceeds. Were clients to have cashed a $\$ 2700$ refund check at a check casher, they would likely have incurred fees of 2 to 3\% (or $\$ 54$ to \$81), far in excess of these charges (Tufano and Schneider 2004). Block priced the card competitively to be attractive to consumers, by offering lower prices and reduced financing charges for some products if the client elected to take the Emerald Card prior to the beginning of the tax season, Block publicly announced a goal of opening one million Emerald Card accounts; it exceeded that number considerably.

For each of these cards, we observe the transactions that add or subtract value from the balance, which provide insight into the breakdown of merchant versus ATM transactions and the nature of the merchant transactions. In contrast to household or consumer surveys, which may suffer from recall biases and measurement errors, these commercial financial records give a precise accounting of the behavior of each Emerald Card consumer.

\footnotetext{
${ }^{9}$ A debit account with "courtesy overdraft" would allow a consumer to exceed the available balance, but the consumer would be charged a fee (often $\$ 25$ to $\$ 30$ ) and required to remediate the overdraft quickly.

${ }^{10}$ The fee schedule for the Emerald Card includes: $\$ 0$ for card acquisition; $\$ 0$ for merchant purchase (either signature, PIN, or PIN with cash back); $\$ 1.50$ per ATM withdrawal (plus fees charged by ATM owner); $\$ 15$ for 'over-the counter' withdrawals at a bank (up to \$9,999); $\$ 2.50$ for each live-agent customer service call (2 free calls per month); and a \$2.50 monthly fee (waived for the first 3 months, if any subsequent deposits are made, or if the balance is $\$ 0$ ).
} 


\section{$\underline{\text { Loan and Settlement Options: Revealing Credit Constraints }}$}

While Block is unique among tax preparers in offering a quasi-bank account to its customers, many commercial preparers (in conjunction with banking partners) make credit available to their customers at tax time We use the endogenous decision by the refund recipient regarding refund settlement or loans to identify their credit constraints or impatience.

All of the individuals in our sample could have received a refund check or direct deposit from the Internal Revenue Service at some point in the winter of 2007 with no additional fees (beyond the cost of tax preparation.) The length of time from filing until refund receipt varies with the type of filing (paper or electronic) and method of refund disbursement (check or direct deposit.) An electronically filed return with a refund directly deposited into the client's existing bank account can be received in as little as eight days (or 15 days if a check is mailed.) A paperfiled return with a cash refund check issued by the IRS can take up to eight weeks (perhaps a week less, if directly deposited.)

Block offers a number of products to accelerate the payment of cash to filers expecting refunds. ${ }^{11}$ These products are summarized in Table 1. Our measure of impatience or credit constraint is the amount of time they choose to accelerate this receipt relative to their tax filing date. At the least constrained end of the spectrum are customers who choose to wait until the IRS processes their return and issues a refund: those choosing the Refund Anticipation Check, or RAC settlement option. For a \$29.95 fee, Block (and its partners) facilitates the electronic deposit of the refund into an account, providing the filer with funds once the IRS has deposited the refund into the account, usually 8-15 days after filing. Users of RACs can also have their tax preparation fees deducted from their refund, and do not have to pay these fees in advance of

\footnotetext{
${ }^{11}$ Block also made available a number of savings products to consumers, including a high yielding savings account and an IRA product; in some locations, it also made savings bonds available to clients. We do not have data on the use of these products in this study.
} 
receiving their refund. This product is particularly valuable to households without bank accounts—who were hence unable to request direct deposit—and therefore have to wait 7 to 8 weeks to receive a paper check. In our sample, RAC users exhibit the lowest level of impatience or credit constraints, receiving money between $\mathrm{T}+8$ to $\mathrm{T}+15$, where $\mathrm{T}$ is the date of tax filing, and paying \$29.95 to speed up access to cash by five to seven weeks. Note that a RAC is not a loan; no funds are disbursed until the refund is received from the IRS. (Unfortunately, clients who elect to simply receive direct deposit, or a refund check from the IRS, are not in our database, as these clients typically do not receive an Emerald Card).

Clients electing a classic "Refund Anticipation Loan" (RAL) borrow in order to receive funds even earlier than RAC clients. Block arranged for the client to get a short-term loan from their partner, HSBC, to the client, for an amount less than the anticipated refund. The refund effectively served as collateral for the loan. Clients choosing a RAL return a day after filling to collect their funds, or at date $\mathrm{T}+1$. A “Classic RAL” cost a $\$ 29.95$ administrative fee, plus a finance charge, calculated at a 36\% APR. Thus, a \$2,500 loan would incur a total cost of $\$ 56$, while a $\$ 3,000$ RAL would incur a total cost of $\$ 62.14 .{ }^{12}$

An "Instant Refund Anticipation Loan (IRAL)" is similar to a RAL, except that the client receives a loan on the same day $(\mathrm{T})$, rather than returning the next day. Once a loan is approved, the proceeds are available in the Emerald Card within approximately 2 hours. Fees for IRALs are higher than for RALs; in particular customers paid an additional fixed charge of \$20 in addition to the RAL charges to get money one day quicker than had they used a RAL. Customers who request IRALs were subject to credit scoring; those with weak credit might receive less than

\footnotetext{
${ }^{12}$ Block set its rates to make it attractive to use the Emerald Card. Without the card, the financing charge would have been closer to 60\% than the 36\% for Emerald Card users for both RALs and IRALs.
} 
the amount of IRAL they sought. This partial-loan is known as a Partial IRAL or PIRAL. Throughout this paper, we categorize IRAL and PIRAL clients together.

An "Instant Money Advance Loan (IMAL)" is a loan product offered before the tax season starts, available as early as October 15. Clients produce pay stubs and other information, from which Block and its partner bank, HSBC, calculates the estimated tax refund, and advances a portion of the estimated refund. This product requires credit approval. The IMAL user obtains funds considerably before tax preparation; without an IMAL, the customer would have had to wait until at least early January before the necessary W-2 forms were available, and likely would not receive a refund before January 15 , even if she filed electronically as quickly as possible. Thus, an IMAL enables a client to receive funds as early as $\mathrm{T}-90$. If the loan proceeds were loaded onto an Emerald Card, the only fee for the IMAL was the 36\% APR financing charge. (If taken as a paper check, an additional $\$ 25$ was charged. $)^{13}$

The fees on these products must be understood in contrast to the fees available elsewhere for small dollar unsecured lending. For example, Skiba and Tobacman (2007) report the typical payday lender charges $18 \%$ of the value of a paycheck for two weeks of credit. Payday lenders typically would not lend as much as lent in these loans, but were they to do so, a client with a \$2500 loan would pay fees of \$375 for each two week period. In contrast, the Block financing charge of 36\% APR, taken over a comparable two week period for a $\$ 2500$ loan, would be about \$35, excluding fixed administrative fees detailed above. Block’s early season (IMAL) fees were also reportedly lower than those charged at competitors (See Tufano, Roy and Ekins 2007 and Wu and Fox 2006).

In functional terms, the RAL, IRAL and IMAL are loan products as they allow filers to receive cash more quickly than the IRS processes would otherwise permit. Through their

\footnotetext{
${ }^{13}$ See http://www.consumerfed.org/pdfs/Paystub_RALs_Report_Final112906.pdf (visited January 27, 2008).
} 
selection of these products—and the fees they are willing to pay—clients reveal their "impatience" to receive money, or their credit constraints. Products which provide money earlier or more quickly are more expensive than those that provide money later or more slowly. We therefore rank clients' level of credit constraint as greatest for those who choose an IMAL who demand money soonest (although the fees for IMALs are arguably less than for other loans.). For in-season loans, we rank credit constraints as greatest for those who choose an IRAL, a RAL and finally a RAC, each of which demands greater immediacy and pays additional fees for this immediacy. This variation drives our analysis. We use the term "credit constraints" to reflect the source of variation revealed by the settlement and loan choices. We think that the choice of this credit reflects the lack of other lower-cost credit alternatives. Another view is that the loan choices reflect differences in liquidity (or cash flow) constraints, or impatience, or a combination of these factors. ${ }^{14}$ Whatever the label, revealed loan and settlement choices reflect real differences among households' willingness and ability to trade present consumption for future consumption. For the sake of exposition, we will use the term 'credit constraints' throughout the paper.

There are sound theoretical reasons to believe expansion of access to consumer credit is beneficial, for example: facilitate intertemporal consumption substitution, allow the purchase of consumer durables, and to smooth short-run consumption when hit with negative shocks. The literature on credit constraints (as well as paycheck receipt) described above finds that money made available by relaxing credit or liquidity constraints is generally spent, and spent relatively quickly. We therefore expect tax settlement products result in spending. Agarwal, Liu and

\footnotetext{
${ }^{14}$ Truly impatient households could have adjusted withholdings or claimed Advance EITC to reduce taxes withheld and thus the refunds payable at tax time. The households in our study may be those who are using excess withholding as a commitment device in the long run, but loans as a means to accelerate this forced saving in the short-run.
} 
Souleles' (2007) findings suggest that the 2001 tax rebate led to more spending by the credit constrained. If this were to hold in our sample, we would expect to see greater spending-or more rapid spending — among the most credit constrained. Finally, using Consumer Expenditure Survey data, Souleles (1999) found that consumption of food and nondurables increased for the most constrained refund recipients, as measured by their liquid wealth normalized by earnings. With our finer data, we can look for a similar result.

\section{Data and Methodology}

We study 1.544 million clients of H\&R Block who got an Emerald Card in the period October 2006 through April 2007. These individuals are slightly less than $10 \%$ of the 15.9 million U.S. retail clients served by the firm in that tax season and 37\% of its 4.2 million loan clients. ${ }^{15}$ These individuals are spread throughout the entire United States.

The underlying transaction data shows the zip code of the Emerald Card user, her transactions, and the form of loan or settlement project selected by the filer. Transaction and loan data is obviously proprietary, and the research team was not given direct access to any confidential customer information. Rather, we submitted database queries which were executed by Block staff. The data to which we have indirect access includes the initial load date of the card, the settlement or credit product(s) used (e.g. RAC, RAL, IRAL, and/or IMAL), the zip code of the client, and detailed transaction information about how the client used the card. We observe reloads, cash withdrawals (from an ATM, or via a bank teller), and details of merchant purchases. We have transaction data from the date of card loading (starting as early as November 1, 2006 for an IMAL) through October 13, 2007, which would include transactions

\footnotetext{
${ }^{15}$ http://media.corporate-ir.net/media_files/irol/76/76888/ShareholderMtg090607Presentation.pdf (visited January 27, 2008).
} 
six months after the close of tax season. We were also given access to an aggregated database containing information at the zip code level. While Block has tax return data for each of the Emerald Card holders, we were not given even indirect access to this data for our analysis.

Consumers could choose more than one of the loan products. For example, a customer could take out an IMAL in November, followed by a RAL in January. We rank their relative degree of credit constraint based on the set of products they chose. Table 2 gives the sample size and the average total amount loaded on the card from the tax refund. In total, we have data on over 1.41 million Block customers who took out loans and 128,697 who expedited their refunds through the RAC product.

We map credit constraints to the choice of products. Those clients who simply sought a RAC were the most patient, willing to wait a week or two for their money. Next are RAL users, who sought funds within a few days of filing, then IRAL users, who sought their money the same day. The most impatient were those taking out IMALs, who sought to accelerate their funds by a few months. People taking out IMALs in conjunction with other loan products were ranked as a function of the other product with IMAL/IRAL users considered the most credit constrained.

While we do not have access to filer-level data, we can broadly characterize the population in our sample, which is disproportionately drawn from low to moderate income families. Tufano and Schneider (2004) report that in 2004 58\% of H\&R Block’s retail tax clients had adjusted gross incomes of under $\$ 30,000$. Rose, Schneider and Tufano (2006) report that Block serves one third of all households with incomes under this level. While there are no published figures on the demographics of IMAL and RAC users, some studies have looked at RAL users. RAL purchasers tended to have lower educational attainments ( $30 \%$ of respondents 
without a high school degree had purchased a RAL versus $23 \%$ of those who graduated from high school, $12 \%$ of those who had graduated from college, and $18 \%$ overall) and lower incomes (25\% of those with household income of under $\$ 50,000$ reported purchasing a RAL). In addition, respondents with children were more likely to have purchased a RAL (26\%). Larger shares of African Americans (28\%) and Latinos (21\%), than whites (17\%) purchased a RAL (Wu and Fox, 2005). We are confident that our sample largely represents low to middle income Americans. Within this group, however, we observe different settlement and loan choices.

Before we analyze spending patterns, we note four important caveats. First, we cannot observe the individual characteristics of people selecting these products. Product choice is clearly endogenous, and could be related to unobservable characteristics such as wealth, income, family structure, etc. We use loan and settlement activity as a proxy for credit constraints which are likely to be the product of more fundamental family economics, alternative credit options, and financial literacy. A further complication is the fact that the IMAL product is typically obtained prior to the end of the year, while the RAC, RAL, and IRAL products are obtained at the time of tax filing. Observed IMAL behavior may therefore vary from RAC, RAL, and IRAL clients not only because the clients are particularly impatient, but also because clients choosing this product use the proceeds for holiday shopping.

Second, we cannot observe spending patterns of those people who did not seek to use the Emerald Card product. We suspect that these people are likely those who are the least credit constrained, and are banked. Therefore our findings apply to a sample of those who are predominantly credit constrained and unbanked. We observe only approved loans, not loan applications. However, the approval rate for these products is quite high: roughly $84 \%$ for a RAL and 94\% for an IRAL. (IRAL approval rates are typically 60-65\%, but HSBC offered 
through Block a 'guaranteed approval' product during the tax season of our analysis, hence the high approval rate). Our sample therefore omits some individuals who were not approved for a loan product; these are presumably the most credit constrained. Furthermore, some people seeking RALs or IRALs might have been turned down and taken RACs instead, which would tend to reduce any differences we observe.

A third caveat is that research cited earlier has shown that spending patterns depend on the type of transaction medium used (credit card versus cash). Our spending data relates to a form that has not been well studied (pre-paid cards), but may not be representative of either cash or credit card patterns. In addition, we observe only card activity, which may not represent all spending. However, given the economy-wide move to consumers using debit cards for spending, this payment medium is a relevant and important one to study. ${ }^{16}$

Finally, we can observe the spending from the Emerald Card, but not other spending by these customers. Customers might engage in some sort of mental accounting where they used the proceeds from their Emerald Card differently than the monies regularly received. Even so, we can interpret our results in the context of existing survey work on spending from the EITC refunds, as referenced above. At a minimum, our results provide new and additional data on how EITC monies are spent.

\section{Baseline Spending Patterns}

Our fundamental research strategy is to study the differences in spending among the different groups of consumers as defined by their self-revealed impatience. Prior to looking at

\footnotetext{
${ }^{16}$ Industry sources note that the number of debit card transactions exceeded the number of credit card transactions for the first time in 2006. See http://www.creditunions.com/home/articles/template.asp?article id=2183 (visited January 20, 2008).
} 
these differences, we first report the aggregate data on the three key spending measures: spend down; means of spending; and merchant activity.

Speed of spend down can be measured in a wide variety of ways, but broadly one can look at spending per unit time (e.g., average spending per day) or the time to reach a certain level of spending (time to spend down). Given that prior work on EITC refunds has focused on spenddown speeds, (Beverly, Schneider and Tufano 2006), we present the latter formulation. We analyze the speed at which the clients spend down the balance, measured by the amount of time until the Emerald Card's balances are exhausted. For this test, we define a card as exhausted by the first date the balance falls below $\$ 5$ (For reference, the average initial load is $\$ 2,353$ —parts of the refund not loaded onto the card include amounts for tax preparation fees or amount saved in one of Block's saving or IRA products). Spend down is therefore slower if a consumer debits the card less or reloads the card with additional funds. Table 3 indicates that the speed at which the card balances are exhausted. Cards are rarely exhausted entirely on their first day. Immediate depletion can be easily achieved by visiting nearly any bank, which, for a small fee (about $\$ 15$ ) would provide the entire balance in cash to the customer. Rather, cards tend to stay active for longer, with $27 \%$ having a balance of over $\$ 5$ after three months.

A second spending measure is the way in which funds are removed from the Emerald Card. A customer can take out cash at an ATM or use the card at a merchant location. We do not have information about the uses for cash taken out from ATMs, but it may be that the primary use of this cash is to pay bills where MasterCard is not accepted, which would include rent, which the literature suggests is an important use of the EITC (Smeeding, Ross, and O’Conner, 2000). Client surveys done by Block in 2005 suggested that RAL users planned to use their loans to repay bills, loans and rent. However, cash withdrawals could also be used for a 
variety of other purposes. Table 4 gives the amount spent from Emerald Cards in our sample by method of spending. The majority (56\%) is taken out either as ATM withdrawals or as withdrawals from banks, $41 \%$ is spent at merchants on goods and services, and the balance is spent on miscellaneous charges such as fees.

A third measure of spending is to observe the merchants at which the card is used. A merchant category code is assigned to each Emerald Card purchase. In the data, there are 614 codes: some merchants (e.g., airlines, hotels) have their own code, while most are assigned to categories, such as “Carpentry,” “Discount Stores,” or “Eating Places, Restaurants.” To facilitate analysis, we aggregate these 614 codes into 28 broader categories. Appendix A shows the disaggregated codes and our groupings of them.

Table 5 lists the top 10 categories of merchant expenditures, which account for 85\% of all merchant activity. The second column gives the amount spent on Emerald Cards in the indicated category, while the third column gives the share of total expenditures for that category. For reference, data from the 2006 Consumer Expenditure Survey is given in the final column, which indicates the share of non-housing expenditure a family with one parent and at least one child, earning $\$ 35,491$, would have spent on the indicated categories. While some categories are roughly in line with CEX figures (e.g., entertainment, and health), Emerald Card clients spend proportionately less of their refunds on groceries, and less on transport, utilities, and restaurants, compared to routine expenditures by roughly comparable Americans. (However, we again note that we do not observe how cash is spent.)

In broad terms, the spending patterns do not immediately suggest profligacy: the biggest single merchant class is grocery stores ${ }^{17}$, followed by automobile expenses (including gas).

\footnotetext{
${ }^{17}$ We can identify the merchant, but not the exact purchase. For example, within grocery stores we cannot tell the spending on food versus household supplies, tobacco, or in some states, alcohol.
} 
Together, these two items account for $37 \%$ of all merchant expenditures. If we add necessities, utilities and health, these categories account for 53\% of all merchant spending. Only "Entertainment" and "Restaurants" are clearly discretionary items, but together they comprise only $13 \%$ of merchant expenditures. Durable purchases, such as appliances, would tend to be fall in three categories: durable goods, discount stores, and retail. They therefore account for at most $19 \%$ of total Emerald Card expenditure.

\section{Spending Patterns and Credit Constraints}

The settlement or credit option chosen by the customer is our measure of credit constraints or impatience. Based on the evidence from prior related studies, one might posit the following relationships:

a. Rate of Spending: Credit constrained individuals might spend their money faster, as the decision to pay fees to receive cash sooner than otherwise might indicate a need or desire for quick money.

b. Mode of Spending: Credit constrained individuals might spend more of their money in the form of cash, to the extent that we interpret cash purchases as representing the payment of rent, housing expenses, repayment of debt, etc. that cannot easily be done in a merchant transaction and which are more "necessities" than luxuries.

c. Merchant Spending: Credit constrained individuals might spend more of their merchant dollars for “necessities” such as groceries and auto expenses, and less on entertainment and eating out. An alternative hypothesis is that they may be impatient to spend on more pleasurable activities. 
The next tables indicate how these measures vary by product choice of the client. The clearest comparisons are between those choosing a RAC, a RAL, or an IRAL, since they are all offered at the same point in time (when the client files taxes), and each involve a single payment to the client. To avoid problems with censoring, we look at accounts opened prior to April 1, 2007, meaning we observe at least six months of data for each account. We also report the spending patterns for pre-tax-season IMAL users, many of whom also used another settlement or loan product at the time of tax filing. For these clients, we would expect a similar ordering with respect to the tax-time product usage.

More constrained clients spend money more rapidly, as indicated by the second through fourth columns of Table 3. The speed of spend-down indicates that IRAL customers drain their accounts the most quickly, followed by RAL, followed by RAC. The differences are statistically significant, but not very large in size: for example, after three months, $28 \%$ of those choosing a RAC maintain a balance over \$5, against $24 \%$ of those choosing a RAL, and $21 \%$ of those choosing an IRAL.

Among IMAL users, the relative speed of spend down is not as clearly related to their tax time product usage. One seemingly odd finding is that clients who took out only IMALs, and were therefore among the most constrained, had more funds left on their Emerald cards after one to three months than did those clients who used a tax-time settlement or loan product. This may be explained by the fact that IMAL clients typically received a loan with a value equal to a portion of their refund in the pre-season, and thus enjoyed further deposits when the refund was settled. However, within the IMAL users who also took out a tax-season loan, the ordering of spend down is not clearly related to the immediacy of cash flow delivered by the loan. 
With respect to the cash/merchant split, we find that the various groups withdraw funds in similar ways. Table 6 gives the share of spent balances that are withdrawn as cash, used to pay fees or send transfers, or spent at merchants, by revealed constraint levels. We find little support for the hypothesis that more constrained households withdraw a larger share of funds in the form of cash. The share withdrawn in cash increases with our measure of credit constraint for households choosing one of three similar products (RAC vs. RAL vs. IRAL), but those choosing IMALs withdraw less in cash than those choosing RALs or IRALs. This could reflect the conjecture that IMALs are more likely used for end of year holiday spending, some of which can be done at merchants accepting MasterCard. However, even among IMAL users, the percent withdrawn in cash is not increasing in the level of revealed credit constraint.

To test how spending varies across groups as a function of their revealed credit constraints, we compare expenditures of six groups identified in Table 2. To control for unobserved heterogeneity attributable to geographic location, we comparing client types within the same zip code to each other. These geographic zip code fixed effects would jointly capture demographic differences across zip codes as well as differing costs of living. We estimate the following equation:

$$
\begin{aligned}
& \text { (1) } \text { Share }_{\mathrm{i}, \mathrm{z}}=\mathrm{a}_{\mathrm{z}}+\beta_{2} *\left(\mathrm{RAL}_{\mathrm{z}}\right)+\beta_{3}\left(\mathrm{IRAL}_{\mathrm{z}}\right)+\beta_{4}\left(\mathrm{IMAL}_{\mathrm{z}}\right)+\beta_{5} *\left(\mathrm{IMAL}_{-} \mathrm{RAC}\right. \\
& \mathrm{z})+\beta_{6} *\left(\mathrm{IMAL}_{\mathrm{RA}} \mathrm{RAL}_{\mathrm{z}}\right)+\varepsilon
\end{aligned}
$$

where share ${ }_{g, i, z}$ is the percentage of spending on merchant category $i$ of product group $g$ in zip code z; a is a zip code fixed effect, RAC users are the omitted category, and the other variables are dummy indicators indicating which product group of Table $\mathbf{2}$ the client falls into.

Results are reported in Table 7 for the 10 largest expenditure categories. For reference, the unconditional share (averaged across all types in all zip codes) of spending in these 
categories for RAC clients is given in column (1). Columns (2)-(6) report point estimates and standard errors for the coefficients to $\beta_{2}-\beta_{6}$. Each coefficient may be interpreted as the average difference, relative to RAC clients in the same zip code, in the share of expenditure that particular group spends on the given merchant category. For example, the coefficient of -.014 for RAL for the "Automobile and Transport" category indicates that RAL clients spent a 1.4 percentage point smaller share of their expenditure on this category than do RAC households. Similarly, those purchasing both IMAL \& RAL clients spent a 2.9 percentage point smaller share of their income on Automobiles and Transport than RAC clients.

Several patterns stand out. First, relative to RAC clients, more constrained clients spend substantially greater shares of their refunds at grocery stores. For example, IMAL clients spend approximately 20 percent (or 5 percentage points) more on groceries than RAC clients. More constrained spend more on utilities, and less on automobiles and transportation. The extremely constrained (5) and (6) spend substantially less on durable goods and restaurants, but somewhat more on necessities, and more at discount stores. Finally, relative to RAC clients, more constrained households spend a smaller share on health and housing.

\section{The Most “Impatient" Spending}

Instead of borrowing with a RAL, IRAL or IMAL or speeding up their refund using a RAC, tax customers could have waited to get their refunds. The cost of their impatience is reflected in the fees they pay to accelerate the receipt of funds. The benefit of this acceleration is reflected in the immediate consumption made possible with the loan product. Spending in the

first few days of receiving the card may therefore provide the most accurate picture of the 
motives behind the consumer's decision to borrow, as later spending could have been supported had the customer waited to receive her refund.

To operationalize this measure, we look at the spending patterns in the first day, first week, and first thirty days that the Emerald Card is active, for three categories of customers. These results are described in Table 8. The results are striking. Grocery expenditures account for 25\% of overall spending of Emerald Card holders. However, on the first day clients receive their card, groceries account for $30 \%$ of expenditures of RAC clients, $36 \%$ of RAL clients, and $41 \%$ of IMAL clients. These differences are less pronounced when the longer windows of one week and one month are considered, yet still persist. One reason why grocery store purchases may be so predominant on the first day is that grocery purchases tend to be frequent, whereas other purchases tend to be less frequent. ${ }^{18}$ Yet, when one considers that the marginal benefit of these particular loans are to support spending in the relatively short window until refunds would have otherwise been received, the results are still meaningful.

One posited reason for borrowing is to purchase durable goods that provide a stream of consumption; however, IMAL clients spend a significantly smaller share of their refunds in the first month on durable goods; this pattern also holds for the first day and first week for discount and retail stores. Most of the other spending patterns are broadly similar across groups for the time periods considered. These relationships reinforce the notion that severely credit-constrained consumers will likely spend much of their money at grocery stores, not purchasing durables.

\section{$\underline{\text { Conclusions and Further Research }}$}

This chapter provides preliminary data on spending patterns by 1.5 million refund recipients, all of whom used either a loan or settlement product to access refund money faster

\footnotetext{
${ }^{18}$ We thank Annamaria Lusardi for this interpretation.
} 
than the IRS processes would have otherwise allowed. Our results should inform the view of policy makers, financial service professionals, scholars and consumer advocates.

Policy makers may be intrigued by our confirmation of earlier findings that document the fairly rapid speed of spending of refunds, which is relevant for thinking about the economic stimulus impact of tax refunds and rebates. Furthermore, the details about how refunds are spent provide insight into the importance of the EITC program. In particular, the conclusion that a material fraction of funds are used to pay for necessities suggests that the program is central to the lives of the poor. Finally, academics and policymakers may be intrigued by the potential to use a stored value card platform to distribute funds, which enables the analysis of spending patterns without expensive and imprecise surveying and without fees associated with check cashing.

Business people and consumer advocates have sometimes been in opposing camps with respect to their feelings about tax refund loan products. The data we report are fairly sobering, as they show these loans seem to be used to obtain necessities, especially funds spent in the first few days of the loans. Consumer advocates who seek to ban these products should consider how a ban would affect households' ability to consume. Similarly, businesses that are pricing and marketing these products should be mindful that the products are not a luxury for their users.

There is considerably more that these groups, and academics, can learn from the spending data we used. While this paper reports preliminary findings, our hope is to link this information with richer data, either at the individual or zip code level, to better understand the demand for loan products and the differential relationships between credit constraints, spending and savings. 


\section{Sources:}

Agarwal, Sumit, Chunlin Lin, and Nicholas Souleles. "The Reaction of Consumer Spending and Debt to Tax Rebates." Journal of Political Economy (forthcoming).

Barr, Michael S., and Jane K. Dokko. "Tax Filing Experiences and Withholding Preferences of Low- and Moderate-Income Households: Preliminary Evidence from a New Survey." In 2006 IRS Research Conference. Georgetown University Law School, 2006.

Barrow, Lisa, and Leslie M. McGranahan. "The Effects of the Earned Income Credit on the Seasonality of Household Expenditures." National Tax Journal 53, no. 4 (2000): 1211 43.

Baughman, Reagan, and Stacy Dickert-Conlin. "Did Expanding the Eitc Promote Motherhood?" The American Economic Review 93, no. 2 (2003): 247-51.

Beverly, Sondra, Daniel Schneider, and Peter Tufano. "Splitting Tax Refunds and Building Savings: An Empirical Test." Tax Policy and the Economy 20 (2006): 111 - 62.

Beverly, Sondra, Jennifer Tescher, and David Marzahl. "Linking Tax Refunds and Low-Cost Bank Accounts." Center for Social Development, George Warren Brown School of Social Work, Washington University in St. Louis, 2000.

Blumenthal, Marsha, Brian Erard, and Chih-chin Ho. "Effects of the Earned Income Tax Credit on Income and Welfare." National Tax Journal 57, no. 2 (2005): 189-213.

Caputo, Richard. "The Earned Income Tax Credit: A Study of Eligible Participants Vs. NonParticipants." Journal of Sociology and Social Welfare 33, no. 1 (2006): 9 - 29.

Coronado, Julia Lynn, Joseph Lupton, and Louise Sheiner. "The Household Spending Response to the 2003 Tax Cut: Evidence from Survey Data." Finance and Economics Discussion Series, Division of Researech and Statistics and Monetary Affairs, Federal Reserve Board, Washington, D.C., 2005.

Dickert-Conlin, Stacy, and Scott Houser. "Eitc and Marriage." National Tax Journal 55, no. 1 (2002): 25 - 40.

Eissa, Nada, and Hilary Hoynes. "Behavioral Responses to Taxes: Lessons from the Eitc and Labor Supply." Tax Policy and the Economy 20 (2006): 73-110.

Eissa, Nada, and Jeffery Liebman. "Labor Supply Response to the Earned Income Tax Credit." The Quarterly Journal of Economics 111, no. 2 (1996): 605-37.

Ellwood, David. "The Impact of the Earned Income Tax Credit and Social Policy Reforms on Work, Marriage, and Living Arrangements." National Tax Journal 53, no. 4 (2000): 1063-106.

Feinberg, Richard. "Credit Cards as Spending Facilitating Stimuli: A Conditioning Interpretation." Journal of Consumer Research 13, no. 3 (1986): 348-56.

Filer, Larry, and Jonathan Fisher. "Do Liquidity Constraints Generate Excess Sensitivity in Consumption: New Evidence from a Sample of Post-Bankruptcy Households." Journal of Macroeconomics 29, no. 4 (2007): 790-805.

Government Accountability Office. "Earned Income Tax Credit Eligibility and Participation." 2001.

Gross, David, and Nicholas Souleles. "Do Liquidity Constraints and Interest Rates Matter for Consumer Behavior? Evidence from Credit Card Data." The Quarterly Journal of Economics 117, no. 1 (2002): 149-85.

Hayashi, Fumio. "The Effect of Liquidity Constraints on Consumption: A Cross-Sectional Analysis." The Quarterly Journal of Economics 100, no. 1 (1985): 183 - 206. 
Hill, Carolyn, V. Joseph Hotz, Charles Mullin, and John Karl Scholz. "Eitc Eligibility, Participation and Compliance Rates for Afdc Households: Evidence from the California Caseload." State of California, 1999.

Hirschman, Elizabeth. "Differences in Consumer Purchase Behavior by Credit Card Payment System." Journal of Consumer Research 6, no. 1 (1979): 58-66.

Hotz, V. Joseph, and John Karl Scholz. "The Earned Income Tax Credit." In Means-Tested Transfer Programs in the United States, edited by Robert Moffit. Chicago: University of Chicago Press, 2003.

_ _ "Participation in the Earned Income Tax Credit Program for Tax Year 1996." (2002). Jappelli, Tullio, Jorn-Steffen Pischke, and Nicholas Souleles. "Testing for Liquidity in Euler Equations with Complentary Data Sources." Review of Economics and Statistics 80, no. 2 (1998): $251-62$.

Johnson, David, Jonathan Parker, and Nicholas Souleles. "Household Expenditure and the Income Tax Rebates of 2001." American Economic Review 96, no. 5 (2006): 1589-610.

Kneebone, Elizabeth. "A Local Ladder for Low-Income Workers: Recent Trends in the Earned Income Tax Credit." The Metropolitan Policy Program, The Brookings Institution, 2007.

Kopczuk, Wojiech, and Cristian Pop-Cleches. "Electronic Filing, Tax Preparers and Participation in the Earned Income Tax Credit." Journal of Public Economics 91 (2007): 1351-67.

Liebman, Jeffery. "The Impact of the Earned Income Tax Credit on Labor Supply and Tax Payer Compliance." Harvard University, 1996.

Melzer, Brian. "The Real Costs of Credit Access: Evidence from the Payday Lending Market.” University of Chicago, 2007.

Morse, Adair. “Payday Lendes: Heroes or Villains?” University of Chicago, 2006.

Olson, Lynn, and Audrey Davis. "The Earned Income Tax Credit: Views from the Street Level." Center for Urban Affairs and Policy Research, Northwestern University, 1994.

Prelec, Drazen, and Duncan Simester. "Don't Leave Home without It." Marketing Letters 12 (2001): 5-12.

Rhine, Sherrie, Sabrina Su, Yazmin Osaki, and Steven Lee. "Householder Response to the Earned Income Tax Credit: Path of Sustenance or Road to Asset Building." 2005.

Romich, Jennifer, and Thomas Weisner. "How Families View and Use the Eitc: Advance Payment Versus Lump Sum Delivery." National Tax Journal 53, no. 4 (2000): 1245 - 66.

Rose, David, Daniel Schneider, and Peter Tufano. "H\&R Block's Refund Anticipation Loan: Preilous Profits at the Bottom of the Pyramid." In Business Solutions for Reaching the Poor, edited by K. Rangan and J. Quelch. New York: Jossey Bass, 2006.

Runkle, David. "Liquidity Constraints and the Permanent Income Hypothesis." Journal of Monetary Economics 27, no. 1 (1991): 73-98.

Schneider, Daniel, and Peter Tufano. "The San Francisco Working Families Credit: Analysis of Program Applicants." Report to SFWorks and the City of San Francisco, 2006.

Scholz, John Karl. "The Earned Income Tax Credit: Participation, Compliance, and Antipoverty Effectiveness." National Tax Journal 47, no. 1 (1994): 63-87.

. "The Participation Rate of the Earned Income Tax Credit." Institute for Research on Poverty, University of Wisconsin - Madison, 1990.

Shapiro, Matthew, and Joel Slemrod. "Consumer Response to Tax Rebates." American Economic Review 93, no. 1 (2003): 381-96.

Skiba, Paige and Jeremy Tobacman. "Measuring the Individual-level Effects of Access to Credit: Evidence from Payday Loans.” Vanderbilt Law School and Oxford University, 2007. 
Smeeding, Timothy, Katherine Ross, and Michael O'Conner. "The Eitc: Expectation, Knowledge, Use, and Economic and Social Mobility." National Tax Journal 53, no. 4 (2000): 1187-209.

Soman, Dilip, and Amar Cheema. "The Effect of Credit on Spending Decisions: The Role of the Credit Limit and Credibility." Marketing Science 21, no. 1 (2002): 32-53.

Souleles, Nicholas. "Consumer Response to the Reagan Tax Cuts." Journal of Public Economics 85, no. 1 (2002): 99-120.

. "The Response of Household Consumption to Income Tax Refunds." American Economic Review 89, no. 4 (1999): 847-958.

Stephens, Melvin, "'3rd of tha Month': Do Social Security Recipients Smooth Consumption Between Checks?" The American Economic Review, 93, n.1 (2003):406-422 . "Paycheque Receipt and the Timing of Consumption." The Economic Journal 116, no. 513 (2006): 680 - 701.

Thaler. "Mental Accounting and Consumer Choice." Marketing Science 4 (1985): 199 - 214.

— . "Towards a Positive Theory of Consumer Choice." Journal of Economic Behavior and Organization 1 (1980): 39-60.

Tufano, Peter, and Arijit Roy and Emily McClintock Ekins, “H\&R Block 2006” HBS Case Number 307-091. . Boston, MA: Harvard Business School Publishing, 2007.

Tufano, Peter, and Daniel Schneider. "H\&R Block and Everyday Financial Services." HBS Case No. 205-013. Boston, MA: Harvard Business School Publishing, 2004.

Wu, Chi Chi, and Jean Ann Fox. "Still a Bad Deal: Beware Quick Tax Refund Loans." Consumer Federation of America and the National Consumer Law Center, 2005. . "Pay Stub and Holiday RALs: Faster, Costlier, Riskier in the Race to the Bottom." Consumer Federation of America and the National Consumer Law Center, 2006.

Zeldes, Stephen. "Consumption and Liquidity Constraints: An Empirical Investigation." Journal of Political Economy 97, no. 2 (1989): 305-46. 
Table 1: Products

\section{Product}

Instant Money Anticipation Loan (IMAL)

Instant Refund Anticipation Loan (IRAL)

Refund Anticipation Loan (RAL)

Refund Anticipation Check (RAC)

Direct Deposi

Paper check mailed from IRS

Time from Applicatio

Date Available to Disbursal of Money

Oct. 15

On Filing

Same Day

1-2 days

On Filing

8-15 days

On Filing 8 days -7 weeks

8 days -8 weeks

\section{Cost}

Finance charge (36\% APR)

$\$ 29.95+\$ 20$ + finance charge (36\% APR)

$\$ 29.95$ + finance charge (36\% APR)

$\$ 29.95$

none

check cashing fees

\section{Description}

Loan made before taxes can be calculated

Loan made after taxes calculated

Loan made after taxes calculated

Bank account opened on behalf of client;

electronic refund from IRS received; client paid

Requires bank account

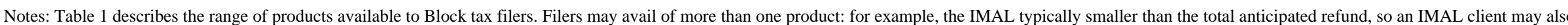

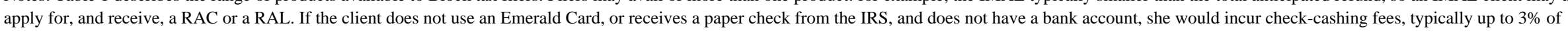
the value of the check. 
Table 2: Sample Size

\begin{tabular}{llcc}
\hline \hline Group & Products & Number of Clients & Average Refund \\
& 1 RAC only & 128,697 & $\$ 1,983$ \\
& 2 RAL only & 451,110 & $\$ 2,220$ \\
3 IRAL only & 412,487 & $\$ 2,192$ \\
& 4 IMAL only & 47,907 & $\$ 2,040$ \\
& IMAL and RAC & 57,283 & $\$ 2,092$ \\
6 IMAL and RAL or IMAL and IRAL & 446,069 & $\$ 2,813$ \\
\hline
\end{tabular}

Notes: Table 2 describes the range of products available to Block tax filers, sorted approximately in the order of revealed credit constraint. Table 1 describes the general features of the various products. 
Table 3. Speed of Spend Down

Average Life of Account (Days)

All

Share of Accounts Empty After:

\begin{tabular}{lrrrrr} 
Same Day & $3 \%$ & $4 \%$ & $5 \%$ & $3 \%$ & $1 \%$ \\
One Week & $18 \%$ & $20 \%$ & $22 \%$ & $23 \%$ & $10 \%$ \\
Two Weeks & $29 \%$ & $30 \%$ & $35 \%$ & $38 \%$ & $17 \%$ \\
One Month & $46 \%$ & $48 \%$ & $53 \%$ & $58 \%$ & $31 \%$ \\
Two Months & $63 \%$ & $63 \%$ & $69 \%$ & $73 \%$ & $52 \%$ \\
Three Months & $73 \%$ & $72 \%$ & $76 \%$ & $79 \%$ & $68 \%$ \\
\hline
\end{tabular}

Notes: The average life of an account is calculated as the number of days following account opening until the account balance falls below $\$ 5$. To minimize truncation bias, calculations are conducted on accounts for which at least six months of data are available (this includes all accounts opened on or before April 15,2 007). Similarly, the share of accounts empty indicates the fraction of accounts whose balance first dropped below $\$ 5$ by the indicated time period. 
Table 4: How Refunds Are Spent

\begin{tabular}{lcc}
\hline \hline & $\begin{array}{l}\text { Total Expenditure } \\
\text { (in millions) }\end{array}$ & Share of Total Expenditure \\
ATM/Cash Out & 2,560 & $56.4 \%$ \\
Merchant & 1,880 & $41.3 \%$ \\
Other/Misc & 105 & $2.3 \%$ \\
\hline Notes: Table 4 gives total expenditure from balances on the Emerald Card, for the \\
sample period (November 1, 2006 through October 13, 2007). The Other/Misc \\
category includes fees.
\end{tabular}


Table 5: On What is Consumer Credit Spent?

\begin{tabular}{lccc}
\hline \hline Category & $\begin{array}{c}\text { Total } \\
\text { Expenditure } \\
\text { (\$ millions) }\end{array}$ & Share & $\begin{array}{c}\text { CEX } \\
\text { Survey } \\
\text { Data }\end{array}$ \\
\hline Groceries & 466.0 & $25 \%$ & $14 \%$ \\
Transportation & 223.0 & $12 \%$ & $25 \%$ \\
Discount Stores & 180.0 & $10 \%$ & $9 \%$ \\
Entertainment & 156.0 & $8 \%$ & $15 \%$ \\
Necessities & 125.0 & $7 \%$ & $10 \%$ \\
Utilities & 122.0 & $6 \%$ & $6 \%$ \\
Durable Goods & 106.0 & $6 \%$ & \\
Restaurants & 103.0 & $3 \%$ & \\
Retail & 64.7 & $15 \%$ & \\
Health & 48.3 & 284.5 & \\
All Other & $1,878.5$ & & \\
Total & Notes: The first two columns of Table 5 gives the amount, and share, spent by \\
all Emerald Card holders, in the top ten categories of expenditure. (For a list of \\
categories, see Appendix A). For comparison, the third column gives estimates \\
from the 2006 Consumer Expenditure Survey of the share of non-housing \\
expenditure of a single-parent household with at least one child, earning \\
\$35,491, for the indicated categories. \\
\hline
\end{tabular}


Table 6: Does Method of Spending Vary With Credit Constraints?

\begin{tabular}{|c|c|c|c|c|c|c|}
\hline & RAC Only & RAL Only & IRAL Only & IMAL only & IMAL and RAC & IMAL and RAL \\
\hline ATM/Cash Out & $55 \%$ & $60 \%$ & $61 \%$ & $55 \%$ & $52 \%$ & $56 \%$ \\
\hline Merchant & $42 \%$ & $38 \%$ & $37 \%$ & $42 \%$ & $45 \%$ & $42 \%$ \\
\hline Other/Misc & $2 \%$ & $2 \%$ & $2 \%$ & $3 \%$ & $2 \%$ & $2 \%$ \\
\hline
\end{tabular}


Table 7: Does Consumption Bundly Vary With Credit Constraints?

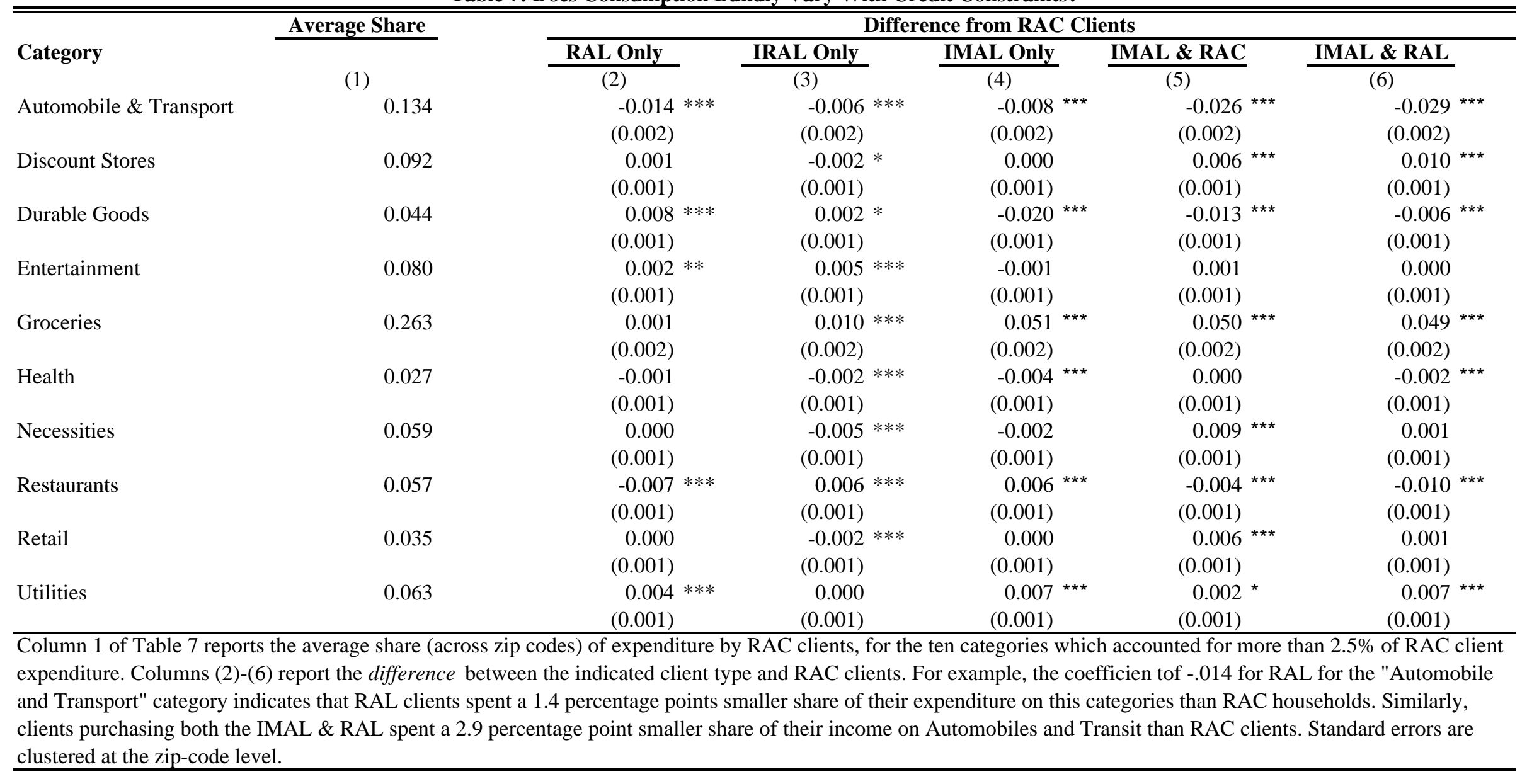


Table 8: Spending Immediately Follow Receipt of Funds

\begin{tabular}{|c|c|c|c|c|c|c|c|c|c|}
\hline \multirow[t]{2}{*}{ Category } & \multicolumn{3}{|c|}{ First Day } & \multicolumn{3}{|c|}{ First Three Days } & \multicolumn{3}{|c|}{ First Month } \\
\hline & RAC & IRAL & IMAL & RAC & IRAL & IMAL & RAC & IRAL & IMAL \\
\hline Groceries & $30 \%$ & $36 \%$ & $41 \%$ & $25 \%$ & $29 \%$ & $34 \%$ & $20 \%$ & $25 \%$ & $29 \%$ \\
\hline Transportation & $7 \%$ & $6 \%$ & $6 \%$ & $8 \%$ & $8 \%$ & $7 \%$ & $10 \%$ & $10 \%$ & $9 \%$ \\
\hline Discount Stores & $15 \%$ & $14 \%$ & $11 \%$ & $13 \%$ & $12 \%$ & $10 \%$ & $10 \%$ & $10 \%$ & $10 \%$ \\
\hline Entertainment & $7 \%$ & $8 \%$ & $8 \%$ & $8 \%$ & $9 \%$ & $9 \%$ & $9 \%$ & $9 \%$ & $9 \%$ \\
\hline Necessities & $1 \%$ & $1 \%$ & $1 \%$ & $2 \%$ & $2 \%$ & $2 \%$ & $3 \%$ & $2 \%$ & $2 \%$ \\
\hline Utilities & $7 \%$ & $7 \%$ & $7 \%$ & $8 \%$ & $8 \%$ & $8 \%$ & $8 \%$ & $8 \%$ & $8 \%$ \\
\hline Durable Goods & $10 \%$ & $7 \%$ & $4 \%$ & $10 \%$ & $8 \%$ & $4 \%$ & $8 \%$ & $6 \%$ & $4 \%$ \\
\hline Restaurants & $2 \%$ & $3 \%$ & $4 \%$ & $3 \%$ & $4 \%$ & $5 \%$ & $5 \%$ & $6 \%$ & $6 \%$ \\
\hline Retail & $4 \%$ & $4 \%$ & $4 \%$ & $4 \%$ & $4 \%$ & $4 \%$ & $4 \%$ & $3 \%$ & $4 \%$ \\
\hline Health & $1 \%$ & $0 \%$ & $0 \%$ & $1 \%$ & $1 \%$ & $0 \%$ & $2 \%$ & $1 \%$ & $1 \%$ \\
\hline All Other & $17 \%$ & $14 \%$ & $14 \%$ & $19 \%$ & $17 \%$ & $17 \%$ & $23 \%$ & $20 \%$ & $19 \%$ \\
\hline
\end{tabular}

Table 8 reports the share of Emerald Card spending for the indicated product category and time period. For example, For RAC users, groceries comrpise 30\% (on average) of all spending incurred in the first day of purchases. For IMAL users, 41 cents of each dollar spent in the first day is spent on groceries. 
Appendix A: Examples of Merchant Category Codes

\begin{tabular}{|c|c|c|}
\hline Bin & Merchant Category & Merchant Type \\
\hline Auto & Automobiles and Vehicles & Moter Vehicle Supplies and New Parts \\
\hline Business & Business & Construction Materials \\
\hline Business & Business Services & Computer Maintenance, Repair and Services \\
\hline Business & Transportation & Courier Services \\
\hline Clothing & Miscellaneous Stores & Sewing, Needlework, Fabric and Piece Goods Stores \\
\hline Consumer & Miscellaneous Stores & Catalog Merchant \\
\hline Direct Marketing & Miscellaneous Stores & Direct Selling Establishments/Door-to-door \\
\hline Discount & Personal Service Providers & Discount Stores \\
\hline Donations & Professional Services & Political Organizations \\
\hline Durables & Business & Durable Goods \\
\hline Educ & Professional Services & Colleges, Universities, Professional Schools \\
\hline Entertainment & Amusement \& Entertainment & Motion Picture Theaters \\
\hline Entertainment & Personal Service Providers & Photographic Studios \\
\hline Entertainment & Service Providers & Trailer Parks and Camp Grounds \\
\hline Financial & Service Providers & Financial Institutions —Merchandise \& Services \\
\hline Groceries & Retail Stores & Grocery Stores, Supermarkets \\
\hline Health & Professional Services & Medical Services and Health Practitioners \\
\hline Housing & Business & Hardware Stores \\
\hline Housing & Contracted Services & Carpentry \\
\hline Legal & Professional Services & Legal Services, Attorneys \\
\hline Luxuries & Clothing Stores & Furriers and Fur Shops \\
\hline Luxuries & Miscellaneous Stores & Jewelry Stores and Silverware Stores \\
\hline Miscellaneous & Professional Services & Intra-Government Purchases-Government only \\
\hline Necessities & Clothing Stores & Men's and Boys' Clothing and Accessories Stores \\
\hline Necessities & Professional Services & Child Care Services \\
\hline Pawn & Miscellaneous Stores & Pawn Shops \\
\hline Remittance & Utilities & Wire Transfer —Money Orders \\
\hline Restaurant & Miscellaneous Stores & Eating Places, Restaurants \\
\hline Retail & Retail Stores & Department Stores \\
\hline Services & Publishing Services & Miscellaneous Publishing and Printing \\
\hline Taxes & Professional Services & Tax Payments \\
\hline Travel & Airlines & Airlines, such as UNITED AIR \\
\hline Travel & Automobile Rentals & Car rental agencies,s uch as Hertz \\
\hline Travel & Hotels and Motels & Lodging, such as HOLIDAY INN EXPRESS \\
\hline Unidentified & Not given & Not given \\
\hline Utilities & Miscellaneous Stores & Fuel Dealers_Fuel Oil, Wood, Coal, LPG \\
\hline Vice & Personal Service Providers & Dating and Escort Services \\
\hline Vice & Retail Stores & Package Stores - Beer, Wine and Liquor \\
\hline
\end{tabular}

Notes: Bin indicates the authors taxonomy; the authors narrowed the merchant category codes into 27 specific product bins. Examples of the raw data are given in the second and third column. 